\title{
Nickel-aluminum diffusion: A study of evolution of microstructure and phase
}

\author{
Alimadadi, Hossein; Kjartansdóttir, Cecilía Kristín; Burrows, Andrew; Kasama, Takeshi; Møller, Per
}

Published in:

Materials Characterization

Link to article, DOI:

10.1016/j.matchar.2017.05.039

Publication date:

2017

Document Version

Peer reviewed version

Link back to DTU Orbit

Citation (APA):

Alimadadi, H., Kjartansdóttir, C. K., Burrows, A., Kasama, T., \& Møller, P. (2017). Nickel-aluminum diffusion: A study of evolution of microstructure and phase. Materials Characterization, 130, 105-112.

https://doi.org/10.1016/j.matchar.2017.05.039

\section{General rights}

Copyright and moral rights for the publications made accessible in the public portal are retained by the authors and/or other copyright owners and it is a condition of accessing publications that users recognise and abide by the legal requirements associated with these rights.

- Users may download and print one copy of any publication from the public portal for the purpose of private study or research.

- You may not further distribute the material or use it for any profit-making activity or commercial gain

- You may freely distribute the URL identifying the publication in the public portal 


\section{Nickel-Aluminum diffusion; A study of evolution of microstructure and phase}

Hossein Alimadadi ${ }^{1, \dagger}$, Cecilía Kjartansdóttir ${ }^{2}$, Andrew Burrows ${ }^{1}$, Takeshi Kasama ${ }^{1}$ and Per Møller ${ }^{2}$ ${ }^{1}$ Technical University of Denmark, Center for Electron Nanoscopy, Fysikvej, building 307, DK2800 Kongens Lyngby, Denmark.

${ }^{2}$ Technical University of Denmark, Department of Mechanical Engineering, Produktionstorvet, building 425, DK - 2800 Kongens Lyngby, Denmark.

† Corresponding Author, E-Mail: hoal@cen.dtu.dk, Tel.: +45 45256494

Keywords: Diffusion; Kirkendall effect; Intermetallics; Aluminum-Nickel binary alloys; Grain boundary diffusion; Electron microscopy

\section{Abstract:}

Microstructural and phase evolution of an aluminum deposit on nickel, after heat treatment at 883 $\mathrm{K}$, is studied by means of various microscopy techniques, i.e. energy dispersive X-ray spectroscopy, backscattered electron imaging, electron backscatter diffraction, ion channeling contrast imaging and scanning transmission electron microscopy. AlNiz crystallites are observed on the aluminum grain boundaries after only $3 \mathrm{~min}$. of heat treatment indicating that nickel and nickel rich phases are the initially diffusing and forming species. Heat treatment for $120 \mathrm{~min}$. or longer results in the formation of $\mathrm{Al}_{3} \mathrm{Ni}_{2}$ and a porous $\mathrm{Al}_{3} \mathrm{Ni} 2 / \gamma-\mathrm{Al}_{2} \mathrm{O}_{3}$ structure at the surface. The $\mathrm{Al}_{3} \mathrm{Ni}_{2}$ layer is composed of two different grain morphologies, indicating the position of a Kirkendall plane, and hence, there is a high diffusion rate of aluminum in this phase. 